\title{
Role of glutathione depletion and reactive oxygen species generation in apoptotic signaling in a human B lymphoma cell line
}

\author{
JS Armstrong ${ }^{1,4}$, KK Steinauer ${ }^{1,4}$, B Hornung1, JM Irish ${ }^{3}$, \\ P Lecane $^{2}$, GW Birrell ${ }^{1}$, DM Peehl ${ }^{2}$ and SJ Knox ${ }^{\star, 1}$ \\ ${ }^{1}$ Department of Radiation Oncology, Stanford University, Stanford, California, \\ CA 94305-5105, USA \\ 2 Department of Urology, Stanford University, Stanford, California, CA 94305- \\ 5105, USA \\ ${ }^{3}$ Department of Molecular Pharmacology, Stanford University, Stanford, \\ California, CA 94305-5105, USA \\ ${ }^{4}$ These authors contributed equally to this work \\ * Corresponding author: J Knox, Department of Radiation Oncology, Stanford \\ University Medical Center, 300 Pasteur Drive, Stanford, CA 943053, USA. \\ Tel: +1 650752 2720; Fax: +1 650498 4093; E-mail: knox@stanford.edu
}

Received 4.4.01; revised 24.8.01; accepted 9.9.01

Edited by B Osborne

\begin{abstract}
The primary objective of this study was to determine the sequence of biochemical signaling events that occur after modulation of the cellular redox state in the B cell lymphoma line, PW, with emphasis on the role of mitochondrial signaling. L-Buthionine sulphoximine (BSO), which inhibits gamma glutamyl cysteine synthetase ( $\gamma$ GCS), was used to modulate the cellular redox status. The sequence and role of mitochondrial events and downstream apoptotic signals and mediators was studied. After BSO treatment, there was an early decline in cellular glutathione (GSH), followed by an increase in reactive oxygen species (ROS) production, which induced a variety of apoptotic signals (detectable at different time points) in the absence of any external apoptotic stimuli. The sequence of biochemical events accompanying apoptosis included a $95 \%$ decrease in total GSH and a partial (25\%) preservation of mitochondrial GSH, without a significant increase in ROS production at $24 \mathrm{~h}$. Early activation and nuclear translocation of the nuclear factor kappa $B$ subunit Rel A was observed at approximately $3 \mathrm{~h}$ after BSO treatment. Cytochrome crelease into the cytosol was also seen after $24 \mathrm{~h}$ of BSO treatment. p53 protein expression was unchanged after redox modulation for up to $72 \mathrm{~h}$, and $\mathrm{p} 21^{\text {waf1 }}$ independent loss of cellular proliferation was observed. Surprisingly, a truncated form of $p 53$ was expressed in a timedependent manner, beginning at $24 \mathrm{~h}$ after BSO incubation. Irreversible commitment to apoptosis occurred between 48 and $72 \mathrm{~h}$ after BSO treatment when mitochondrial GSH was depleted, and there was an increase in ROS production. Procaspase 3 protein levels showed a time-dependent reduction following incubation with BSO, notably after $48 \mathrm{~h}$, that corresponded with increasing ROS levels. At $96 \mathrm{~h}$,
\end{abstract}

caspase 3 cleavage products were detectable. The pancaspase inhibitor zVADfmk, partially blocked the induction of apoptosis at $48 \mathrm{~h}$, and was ineffective after $72 \mathrm{~h}$. PW cells could be rescued from apoptosis by removing them from BSO after up to 48 , but not $72 \mathrm{~h}$ incubation with BSO. Mitochondrial transmembrane potential $\left(\Delta \Psi_{\mathrm{m}}\right)$ remained intact in most of the cells during the $72 \mathrm{~h}$ observation period, indicating that $\Delta \Psi_{m}$ dissipation is not an early signal for the induction of redox dependent apoptosis in PW cells. These data suggest that a decrease in GSH alone can act as a potent early activator of apoptotic signaling. Increased ROS production following mitochondrial GSH depletion, represents a crucial event, which irreversibly commits PW cells to apoptosis. Cell Death and Differentiation (2002) 9, 252-263. DOI: 10.1038/ sj/cdd/4400959

Keywords: apoptosis; reactive oxygen species; GSH; mitochondria; redox

Abbreviations: BSO, L-buthionine sulphoximine; $\gamma \mathrm{GCS}$, gamma glutamyl cysteine synthase; GSH, glutathione; ROS, reactive oxygen species

\section{Introduction}

Therapeutic strategies designed to increase the susceptibility of tumor cells to apoptosis have the potential to significantly augment the efficacy of a variety of cancer treatments. We have previously shown that enhancement of the apoptotic potential of tumor cells increases tumor responses to radiotherapy. ${ }^{1}$ Many chemotherapeutic agents have profound effects on the cellular redox status, ${ }^{2-4}$ and alteration of redox status may play an important role in the induction of apoptosis. ${ }^{5-8}$ We have recently reported that changes in the redox status of cells can modulate the sensitivity of tumor cells to apoptosis induced by uncoupling mitochondrial electron transport with the protonophore carbonyl cyanide $m$-chlorophenylhydrazone. ${ }^{8}$

Cellular redox potential is largely determined by glutathione (GSH), which accounts for more than $90 \%$ of cellular non-protein thiols. ${ }^{9}$ The majority of $\mathrm{GSH}$ is found in the cytosol, ${ }^{10}$ however a small, but significant, percentage of total cellular GSH $(10-15 \%)$ is located in the mitochondria. Mitochondrial GSH is of paramount importance in protecting the organelle from reactive oxygen species (ROS) produced during coupled mitochondrial electron transport and oxidative phosphorylation. ${ }^{10}$

Many agents that induce apoptosis are either oxidants or stimulate oxidative metabolism, while many inhibitors of 
apoptosis are antioxidants or mediators of cellular antioxidant defenses. ${ }^{11}$ Depletion of cellular antioxidant defenses allows for the generation of significant quantities of ROS, which have been suggested to act as a signal for the induction of apoptosis. ${ }^{12}$ However, other investigators have suggested that antioxidant depletion (e.g. GSH), rather than production of ROS, is an important mediator of apoptosis. ${ }^{13}$

GSH is important for many cellular biochemical functions including the regulation of gene transcription, as well as the modulation of apoptosis. ${ }^{7,14}$ The binding of many transcription factors to their cognate DNA sequences is sensitive to the redox environment. ${ }^{14,15}$ One redox sensitive transcription factor involved in cell proliferation is nuclear factor kappa $\mathrm{B}(\mathrm{NK} \kappa \mathrm{B}) .{ }^{14-16} \mathrm{NF}_{\kappa} \mathrm{B}$ translocation to the nucleus can induce the transcription of a variety of genes, including cytokines, cell cycle regulator proteins and anti-apoptotic proteins. ${ }^{17}$ Although it has been suggested that $\mathrm{NF}_{\kappa} \mathrm{B}$ activation is critical for the regulation of the expression of genes mediating cell survival, and may have an antiapoptotic role, ${ }^{18-20}$ others have found that activation of this transcription factor is pro-apoptotic. ${ }^{21-23}$

While, $\mathrm{NF}_{\kappa} \mathrm{B}$ activation may play a role in either cell survival or cell death, expression of the tumor suppressor gene p53 is known to induce either stable growth arrest or apoptosis. ${ }^{24,25}$ In human colorectal cancers, the growth arrest is dependent on the transcriptional induction of the protein $\mathrm{p} 21^{\text {waf1 }}$, but the precise mechanisms involved in p53dependent apoptosis are unclear. However, recently it has been reported that many important genes transactivated by p53 prior to the onset of apoptosis encode proteins that are involved in oxidative stress. ${ }^{26}$ These findings reported by Polyak et al. ${ }^{26}$ suggest that p53 expression results in apoptosis via a three-step process, including the transcriptional induction of redox-related genes, the formation of reactive oxygen species, and the oxidative degradation of mitochondrial components resulting in cell death.

Recently, mitochondria and potential signaling molecules such as cytochrome $c$ released from mitochondria have been reported to be key regulators of apoptosis. ${ }^{27-32}$ Cytochrome $c$ can combine with Apaf-1, and procaspase- 9 to form the apoptosome, ${ }^{33}$ which activates caspase-9, and caspase 3 . Nevertheless, the importance of cytochrome $c$ release as an apoptotic signal has recently been challenged. For example, cytochrome $c$ release from mitochondria has been reported to be the result of cellular redox imbalance rather than a signal committing the cell to death, ${ }^{34}$ and Budd et al. ${ }^{35}$ showed that cytochrome $c$ release was not sufficient for caspase activation or apoptosis in neuronal cells. Activation of caspases may be redox dependent, but the optimal cellular redox environment for activation of caspases is unclear. ${ }^{36,37}$ Reports in the literature suggest that mitochondrial permeability transition (MPT) induction and mitochondrial transmembrane potential $\left(\Delta \Psi_{\mathrm{m}}\right)$ depolarization are apoptotic signals, ${ }^{29-32}$ but we and other investigators have recently reported that $\Delta \Psi_{\mathrm{m}}$ depolarization is a fully reversible event and does not irreversibly commit cells to die. $8,38,39$ Therefore, the role of potential mitochondrial signals in the induction of apoptosis remains controversial.
The primary objective of this study was to characterize the sequence of biochemical events occurring in B cell lymphoma PW cells after modulation of the cellular redox state, with emphasis on the role of mitochondria. The early decline in cellular GSH, in response to BSO treatment, coincided with the induction of mediators of apoptotic signaling including $\mathrm{NF}_{\kappa} \mathrm{B}, \mathrm{p} 53$, and cytochrome $c$ release from mitochondria. ROS generation increased significantly following depletion of mitochondrial GSH, after which procaspase 3 was activated. $\Delta \Psi_{\mathrm{m}}$ was intact in a larger proportion of the cell population at a time when cells were committed to die.

\section{Results}

\section{Apoptosis following BSO treatment}

PW cells were incubated for various times with BSO (1 mM), which depletes GSH from cellular compartments in a time dependent manner, by inhibition of cytosolic $\gamma$ GCS. Apoptosis was then assessed by staining cells with P.I. and using flow cytometry analysis to determine the proportion of hypodiploid (sub-G1) apoptotic cells. Figure 1A shows a time dependent increase in the apoptotic fraction of PW cells following BSO incubation (control (no BSO): $1.5 \pm 0.3 \%, 24 \mathrm{~h}: 2.5 \pm 1.2 \%$, $48 \mathrm{~h}: 5.0 \pm 3 \%$ and $72 \mathrm{h:} 16.4 \pm 3 \%)$.

\section{Commitment to cell cycle arrest is irreversible after BSO treatment for $72 \mathrm{~h}$}

Cells were treated with BSO (1 mM) for $0,12,24,36,48,60$, and $72 \mathrm{~h}$. Cells were then rescued by washing in RPMl and plating them in fresh RPMI for 24, 48 and $72 \mathrm{~h}$. After treatment with BSO $(1 \mathrm{mM})$ for $12-36 \mathrm{~h}$, there was no marked difference in the viability of BSO treated cells compared with untreated control cells, whereas after 48 and $60 \mathrm{~h}$ under the same conditions, there was a significant increase in cell death compared to control cells. After incubation with BSO (1 mM) for $72 \mathrm{~h}$, cells could not be rescued by removing BSO from the media and viability dropped dramatically (Figure 1B,C), with the most cell death occuring in the first $24 \mathrm{~h}$ following washout of BSO from the media (data not shown for 48 and $72 \mathrm{~h}$ following washout of BSO).

\section{Cytosolic and mitochondrial GSH levels following BSO treatment}

Figure $2 \mathrm{~A}$ shows that $\mathrm{PW}$ cells rapidly lost $\mathrm{GSH}$ in a timedependent manner after BSO $(1 \mathrm{mM})$ treatment. At $12 \mathrm{~h}$, total GSH levels were almost 95\% depleted, and GSH was undetectable at $24 \mathrm{~h}$ (Figure 2A). The level of GSH in the enriched mitochondrial fraction of cells treated with BSO ( $1 \mathrm{mM}$ ) for $24 \mathrm{~h}$ was $593 \pm 119 \mathrm{pmol} / 10^{6}$ cells compared to $2460 \pm 203 \mathrm{pmol} / 10^{6}$ cells in control cells (Figure $2 \mathrm{~B}$ ), and was below the limit of detection after incubation with BSO (1 $\mathrm{mM})$ for $48 \mathrm{~h}$ (Figure 2B).

\section{DTT can rescue cells from BSO-induced apoptosis}

PW cells were incubated with BSO with or without DTT for $0-72 \mathrm{~h}$ prior to assessment of apoptosis. Incubation 
A

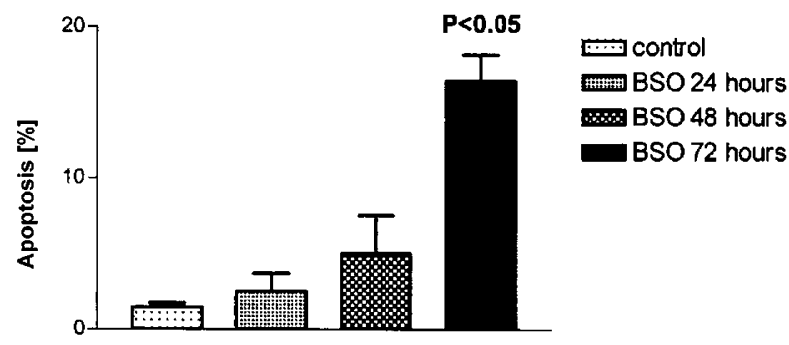

B

Viability of Representative RPMI-Rescued BSO-Treated PW Cells $0 \mathrm{~h}$ BSO 24 h BSO $48 \mathrm{~h} \mathrm{BSO}$ $72 \mathrm{~h}$ BSO

$24 \mathrm{~h}$ Post Wash Out and Incubation in Fresh RPMI

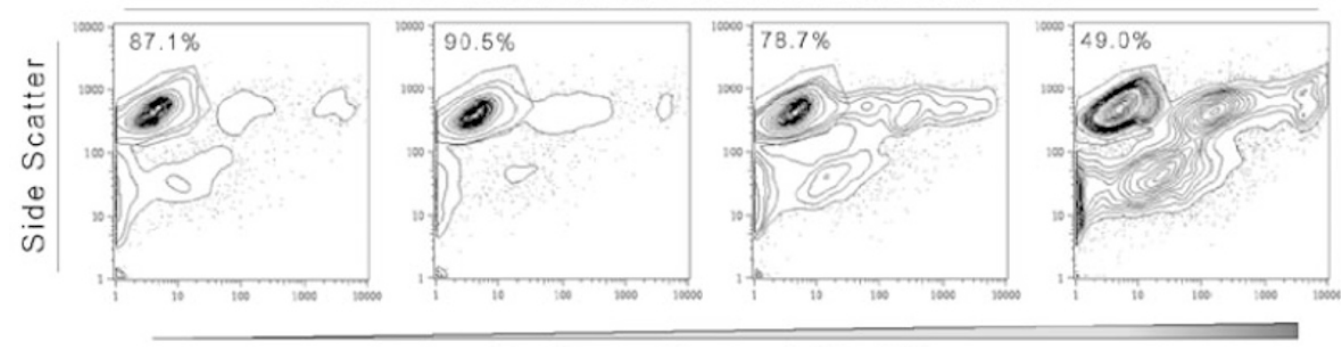

Membrane Permeability $(P I)$

C

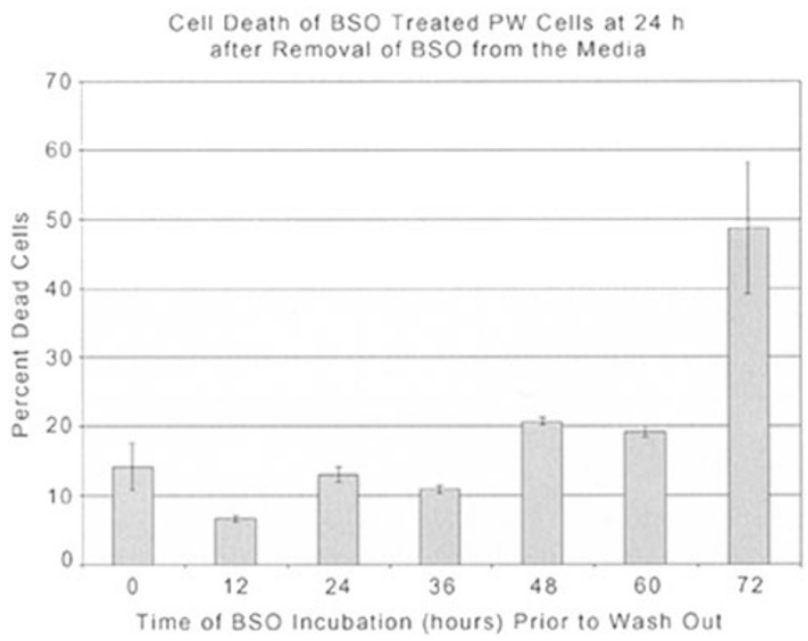

Figure 1 Apoptosis and cell proliferation after incubation with BSO. (A) Apoptosis following incubation with BSO. PW cells were incubated with RPMI containing BSO $(1 \mathrm{mM})$ for $0,24,48$ and $72 \mathrm{~h}$ (as described in the Materials and Methods section). The apoptotic fraction was determined by flow cytometry analysis of PI stained cells (as described in the Materials and Methods section). Data are expressed as mean \pm S.E.M. ( $n=3$ ). (B) Representative plots of flow cytometry data showing rescue of PW cells following incubation with BSO. (C) Graph showing rescue of PW cells following incubation with BSO. PW cells were incubated with RPMI 1640 containing BSO (1 mM) for $0,12,24,36,48,60$ and $72 \mathrm{~h}$. After the incubation period cells were washed in fresh RPMI, seeded at an approximate density of $5 \times 10^{5} / \mathrm{ml}$, and incubated for an additional $72 \mathrm{~h}$. At $24 \mathrm{~h}$ after removal of the BSO, cell viability was determined by counting viable PI stained cells with flow cytometry. Data are expressed as mean \pm S.E.M. $(n=3)$

with BSO alone resulted in a time-dependent induction of apoptosis, whereas the concomitant incubation of DTT with BSO prevented the induction of apoptosis, demonstrating that PW cells could be 'rescued' from BSO-induced apoptosis by incubating them with DTT (Figure 3).

\section{ROS production following BSO treatment}

DCFH-DA was used to indirectly measure cellular generation of hydrogen peroxide $\left(\mathrm{H}_{2} \mathrm{O}_{2}\right)$ before it reacted to form stable organic peroxides. As a positive control, PW cells were incubated with $\mathrm{H}_{2} \mathrm{O}_{2}(100 \mu \mathrm{M})$ for 30 min prior to the 
A

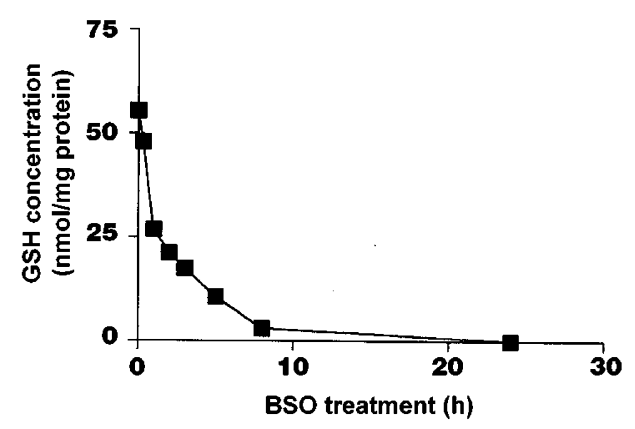

B

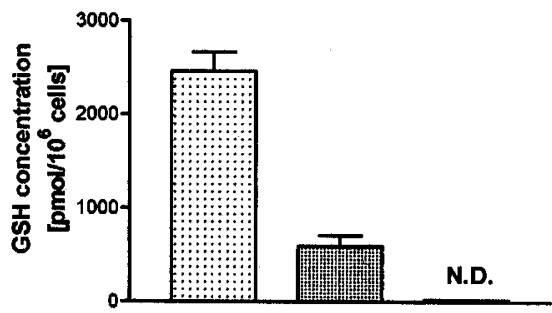

Figure 2 GSH levels in PW cells. (A) Effect of BSO on total GSH levels. PW cell aliquots $\left(4 \times 10^{6} / \mathrm{ml}\right)$ were incubated with RPMI containing BSO $(1 \mathrm{mM})$ for up to $24 \mathrm{~h}$. GSH levels were determined at various times on these samples by the GSH reductase recycling assay described in the Materials and Methods section. The GSH concentration was plotted as a function of time and expressed as $\mathrm{nmol} / \mathrm{mg}$ protein. (B) Effect of BSO on mitochondrial GSH levels. PW cells were treated with BSO for 24,48 and $72 \mathrm{~h}$. Mitochondrial fractions from these cells were isolated as described in the Materials and Methods section. GSH levels were determined using the GSH reductase recycling assay. The GSH concentration was expressed in pmol/ $10^{6}$ cells. Data are expressed as mean \pm S.E.M. $(n=3)$

analysis. Cell samples were incubated with BSO $(1 \mathrm{mM})$ for $0,24,36,48,54,60,72$ and $96 \mathrm{~h}$ prior to collection, and analyzed by flow cytometry for DCF fluorescence on the FITC/FL-1 channel as an indicator of ROS production. Cells with a higher level of DCF fluorescence than untreated controls shifted right on the $x$ axis into the ROS ${ }^{\text {high }}$ compartment (arbitrary units). Figure 4A,B shows that incubation of the control cell population with BSO $(1 \mathrm{mM})$ shifts cells into the ROS ${ }^{\text {high }}$ compartment as a function of time. In addition, Figure 4A,B demonstrate that adding DTT to the media during BSO incubation abolishes this shift into the ROS ${ }^{\text {high }}$ compartment. Figure $4 \mathrm{C}$ is a positive control showing cells treated with $\mathrm{H}_{2} \mathrm{O}_{2}(100 \mu \mathrm{M})$. By comparing Figure $4 \mathrm{~A}$ and $\mathrm{C}$ it is clear that the ROS ${ }^{\text {high }}$ compartment indicates the presence of increased levels of peroxide. After $48 \mathrm{~h}$ of incubation with BSO $(1 \mathrm{mM})$ a significant cell population $(14.0 \pm 1.1 \%)$ has begun to appear in the ROS ${ }^{\text {high }}$ compartment at the same DCF fluorescence level as the population of cells treated with $\mathrm{H}_{2} \mathrm{O}_{2}$ (Figure 4A,B). This observation is consistent with the generation of similar levels of peroxides in the two ROS ${ }^{\text {high }}$ cell populations. At $72 \mathrm{~h}$ there is a significant increase in the non-viable cell population (seen as a new population appearing at the leftmost edge of the $x$ axis). Non-viable cells do not fluoresce since they have lost their ability to entrap the DCFH-DA dye and convert it to the membrane impermeable form DCF (a function of their intracellular esterase activity). Cells without functional esterases are considered non-viable, and the cell population with non-functional esterases is comprised of those cells to the far left on the $x$ axis in the 60 and $72 \mathrm{~h}$ timepoints in Figure 4A. All experiments were repeated in triplicate. Ten thousand events were recorded in each experiment, and data for each cell population (non-viable, viable and hyperfluorescent) is shown as the mean percentage (\% of total population) \pm S.E.M.

\section{Rel A translocation}

Figure $5 \mathrm{~A}$ shows the Rel $\mathrm{A}$ band at $65 \mathrm{k}$-Da following 1,3 and $5 \mathrm{~h}$ of incubation with BSO $(1 \mathrm{mM})$. The earliest time point at which increased nuclear Rel $A$ expression was observed compared to the controls was at $3 \mathrm{~h}$.

\section{p53 expression after BSO treatment of PW cells}

p53 expression was determined following modulation of the redox state in PW cells by incubation with BSO $(1 \mathrm{mM})$. p53 protein was detectable at $53 \mathrm{k}$-Da in both control and BSO (1 mM) treated PW cells without change in the level of expression during the $72 \mathrm{~h}$ incubation period (Figure 5B). A truncated form of p53 protein band was also detected at approximately $50 \mathrm{k}-\mathrm{Da}$ using the $\alpha$ p53 monoclonal antibody DO-1. Truncated p53 was increasingly expressed as a function of time following incubation with BSO $(1 \mathrm{mM})$. Incubation of PW cells with BSO $(1 \mathrm{mM})$ failed to induce the expression of $\mathrm{p} 21^{\text {waf } 1}$ (data not shown).

\section{Release of mitochondrial cytochrome $c$ after BSO incubation}

Cytochrome $c$ release was measured in the cytosolic extracts from PW cells after incubation with BSO $(1 \mathrm{mM})$ for 24 to $96 \mathrm{~h}$ by immunoblot analysis. A time-dependent increase in cytosolic cytochrome $c$ was observed, with cytochrome $c$ first being detected at $24 \mathrm{~h}$ after incubation with BSO (1 mM) (Figure 6).

Activation of procaspase 3 by BSO incubation, and inhibition of apoptosis with zVADfmk. Procaspase 3 activation was assessed following incubation of cells with BSO (1 mM) for 24 to $96 \mathrm{~h}$ in PW extracts by immunoblot analysis. There was a time-dependent decrease in the procaspase 3 protein band, at $32 \mathrm{k}-\mathrm{Da}$, following incubation with BSO $(1 \mathrm{mM})$. At $72 \mathrm{~h}$ caspase 3 cleavage products were observed (Figure 7A). Furthermore, the pan caspase inhibitor zVADfmk, which partially blocked apoptosis induction after $48 \mathrm{~h}$ of BSO treatment, was ineffective after $72 \mathrm{~h}$ (Figure 7B) when caspase 3 cleavage products were evident (Figure 7A).

\section{$\Delta \Psi_{\mathrm{m}}$ in PW cells after incubation with BSO}

PW cells incubated with and without BSO (1 mM) for 24 and $72 \mathrm{~h}$, were stained with TMRM and imaged by fluorescence 
A

Apoptosis Over Time in BSO Treated PW Cells
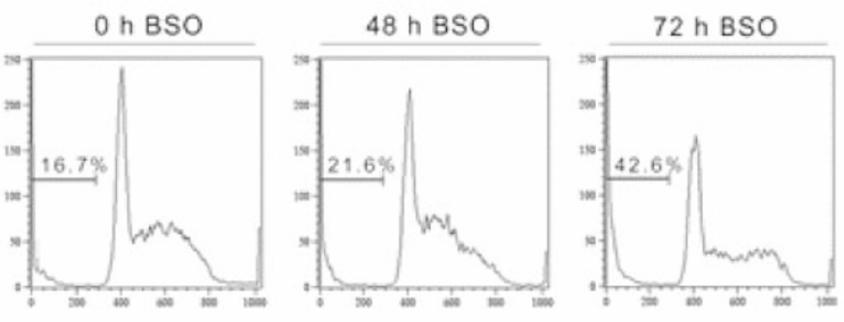

DNA Content (PI/RNAse)
Rescue of BSO-Induced Cell Death by DTT
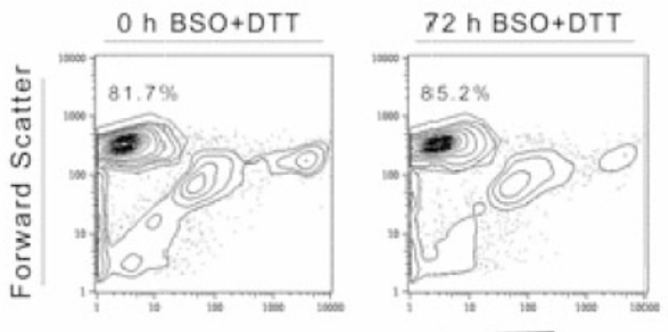

Membrane Permeability (PI)

B

Apoptosis as a Function of Time in PW Cells Treated with $\mathrm{BSO}$ in the Presence or Absence of DTT

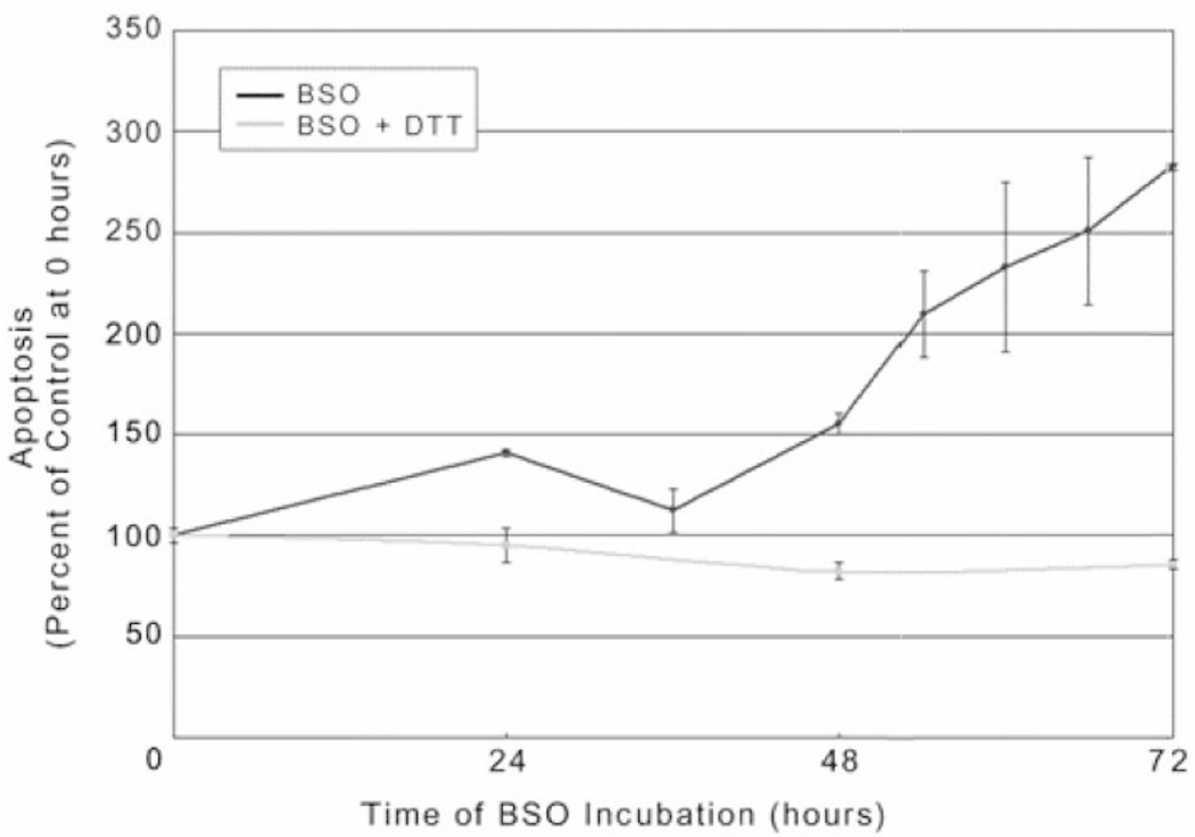

Figure 3 Apoptosis in cells treated with BSO with or without DTT. PW cells were incubated with BSO $(1 \mathrm{mM})$ in the presence or absence of DTT (500 $\mu \mathrm{M})$ for 0 $72 \mathrm{~h}$ prior to assessment of apoptosis by flow cytometry of permeabilized, PI/RNAase stained BSO treated cells, or unpermeabilized, $\mathrm{PI}$ stained cells treated with BSO+DTT. (A) Representative plots of flow cytometry data at key time points showing increasing apoptosis of PW cells as a function of the incubation time with BSO. Apoptosis was determined as the percentage of sub-G1 cells in an ungated population of 10000 events. In BSO+DTT treated samples, cell viability was verified by PI exclusion. (B) Graph of BSO induced apoptosis over time contrasted with very low cell death observed in samples incubated with BSO+DTT. Data in (B) are shown as the mean \pm S.E.M. $(n=3)$ for apoptosis shown as the percentage of control at time $0 \mathrm{~h}$

microscopy. The average fluorescent signal was not significantly different in cells treated with or without $1 \mathrm{mM} B S O$ (24 or $72 \mathrm{~h}$ ) (Figure 8A,B). To further confirm that the $\Delta \Psi_{\mathrm{m}}$ was intact after incubation with BSO $(1 \mathrm{mM})$, cells were treated with $50 \mu \mathrm{M}$ of the uncoupler CCCP, and the fluorescence of at least 20 cells in the microscope field was continuously monitored (Figure 8B). Figure 8A shows representative images of relative fluorescence at time point zero and $10 \mathrm{~min}$ after CCCP treatment. The dissipation of fluorescence was both rapid and simlar in control and BSO treated cells $(1 \mathrm{mM})$, demonstrating the presence of an intact $\Delta \Psi_{\mathrm{m}}$ in both control (untreated) and BSO treated cells prior to
CCCP treatment, with similar kinetics of depolarization following exposure to CCCP.

\section{Discussion}

Cellular redox status is an important regulator of apoptotic potential. The effect of modulating the redox status on apoptotic potential was studied using BSO to inhibit GSH synthesis, and create a progressively oxidizing environment. Prolonged exposure to BSO led to apoptotic cell death within a time frame that allowed us to characterize the sequence of biochemical events involved in BSO-induced apoptosis. 
A)

\section{Representative BSO-Induced ROS Over Time in PW Cells Incubated with or without DTT}
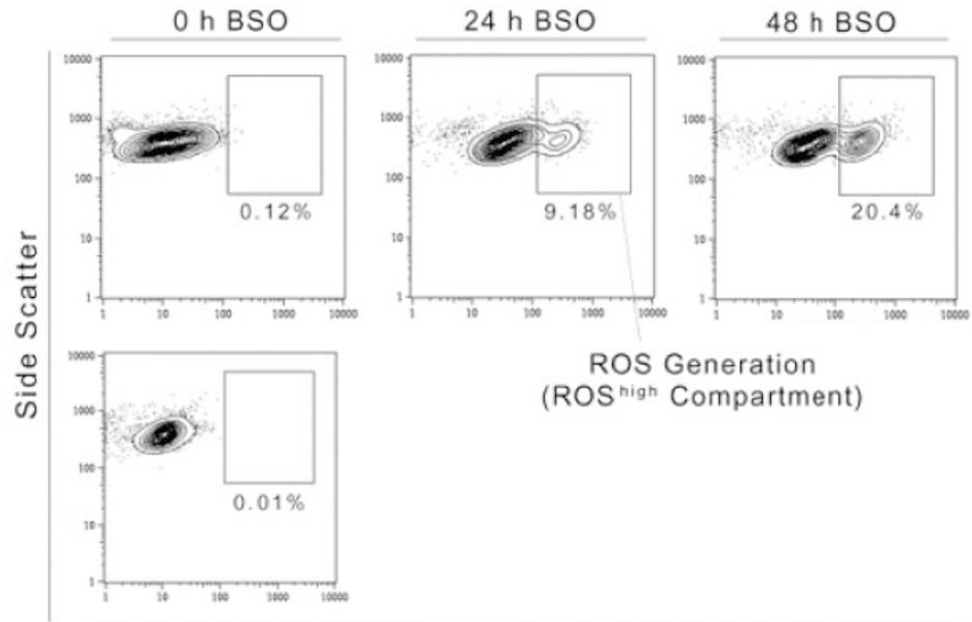

ROS Generation (ROS ${ }^{\text {nigh }}$ Compartment)

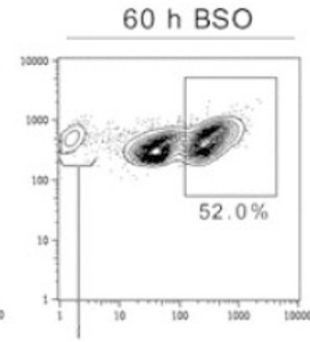

Non-viable Cells

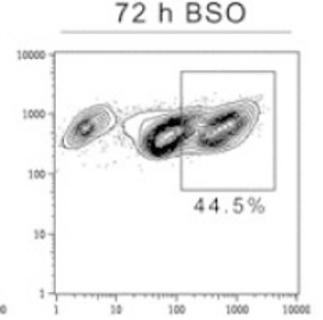

O

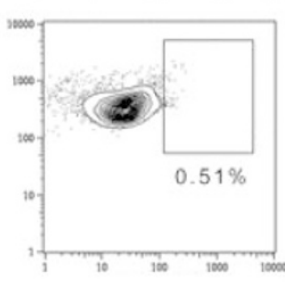

ROS (DCFH-DA)

B) Induction of ROS as a Function of Time in PW Cells Treated with BSO in the Presence or Absence of DTT

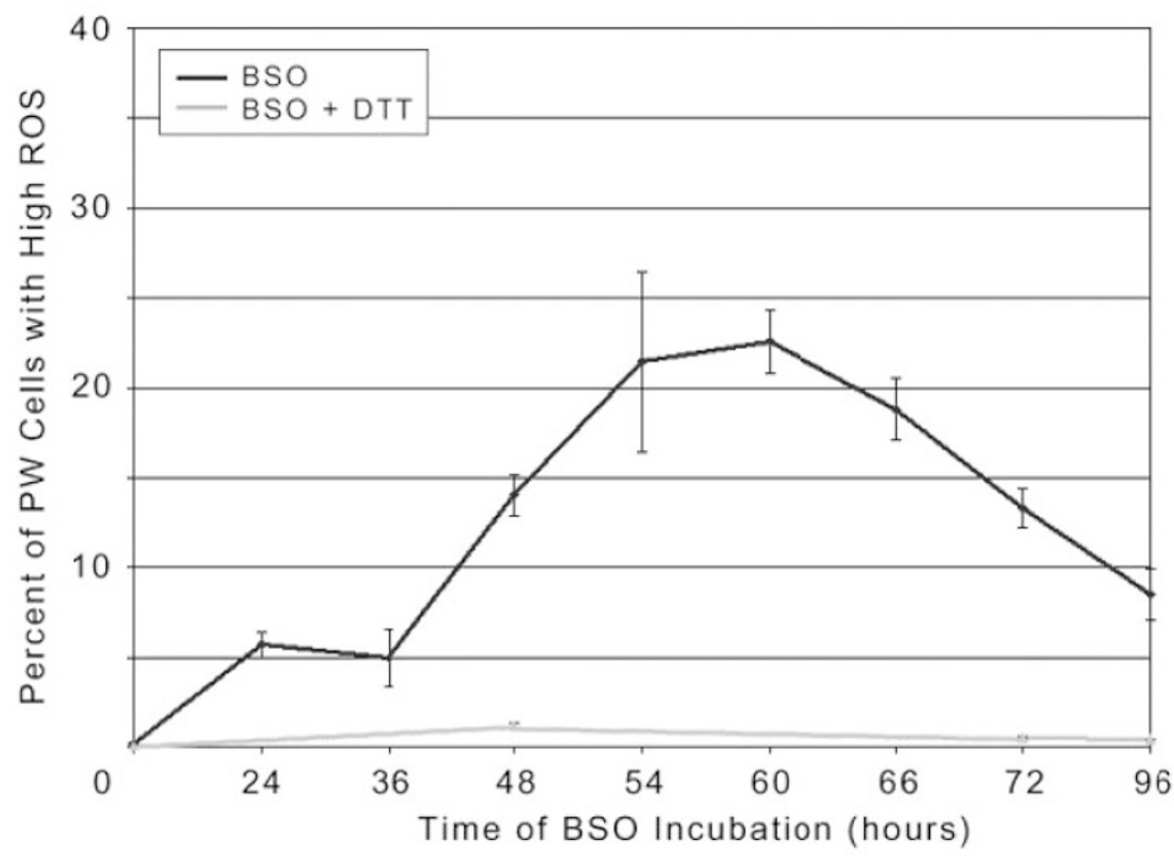

C) $\mathrm{H}_{2} \mathrm{O}_{2}$ Control

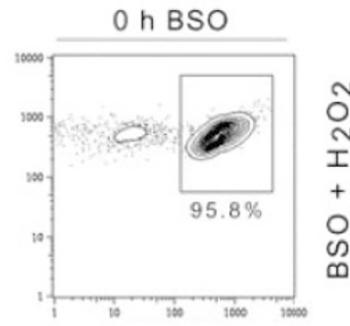

Figure 4 ROS levels following incubation with BSO. (A) Representative plots of flow cytometry data showing ROS levels in PW cells after GSH depletion. PW cells were incubated with BSO $(1 \mathrm{mM})$ for $0,24,36,48,54,60,72$ and $96 \mathrm{~h}$ as described in the Materials and Methods section. $1.0 \times 10^{6} \mathrm{ml}$ cells were loaded with $50 \mu \mathrm{M} \mathrm{DCFH}-\mathrm{DA}$ and incubated at $37^{\circ} \mathrm{C}$ for $30 \mathrm{~min}$. Determination of intracellular ROS generation was performed by flow cytometry analysis of 10000 cells using the FL1 channel in logarithmic mode (as described in the Materials and Methods section). Three cell populations differing significantly in their relative mean fluorescence were observed by flow cytometry analysis: (1) a cell population with medium fluorescence corresponding to viable and untreated control cells, (2) a hyperfluorescent cell population labeled ROS ${ }^{\text {high }}$ corresponding to cells that had generated significant quantities of ROS compared to the positive control sample treated with $\mathrm{H}_{2} \mathrm{O}_{2}(100 \mu \mathrm{M})$, and (3) a non-viable cell population with low fluorescence corresponding to cells that had failed to cleave and entrap DCFH-DA (labeled in the $60 \mathrm{~h}$ timepoint where it first appears). Cell numbers in the ROS ${ }^{\text {high }}$ compartment are expressed as per cent cells of whole population. Results are representative of four experiments. As a control, PW cells were incubated with BSO $(1 \mathrm{mM}) \pm$ DDT $(500 \mu \mathrm{M})$ for $0-72 \mathrm{~h}$ prior to measurement of ROS and representative plots were included in (A). (B) Graph of the induction of ROS as a function of time in PW cells treated with BSO in the presence or absence of DTT. Percentages of cells in the ROS high compartment from $(\mathbf{A})$ were graphed as mean + S.D. $(n=3)$. The dark line represents BSO treated PW cells and the light line demonstrates the contrasting lack of ROS in the cells incubated with both BSO and DTT. (C) Representative plot of the induction of $\mathrm{ROS}$ in $\mathrm{H}_{2} \mathrm{O}_{2}$ treated control PW cells. Control PW cells were incubated with $\mathrm{BSO}+\mathrm{H}_{2} \mathrm{O}_{2}$ for $30 \mathrm{~min}$ prior to staining (as in the $0 \mathrm{~h}$ timepoints in $\mathbf{A}$ ). The shift of $>95 \%$ of the cell population into the ROS ${ }^{\text {high }}$ compartment demonstrates the presence of increased levels of peroxide 
A

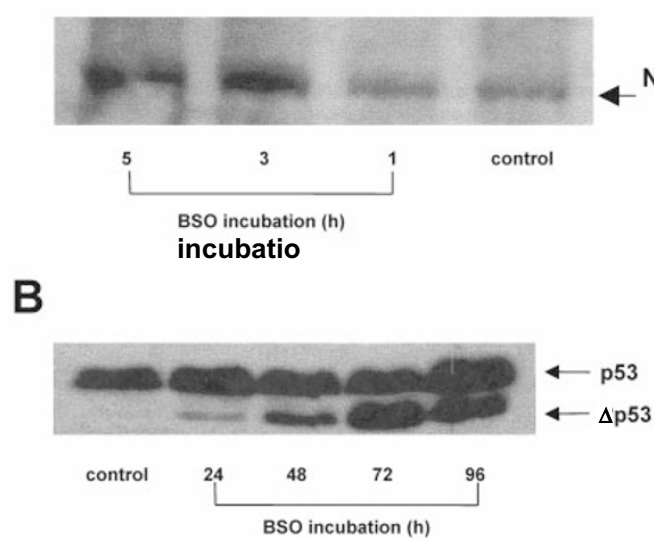

Nuclear Rel A (65 k-Da)

Figure 5 Effect of $\mathrm{BSO}$ incubation on $\mathrm{NF}_{\kappa} \mathrm{B}$ activation and p53 induction. (A) Effect of BSO incubation of $\mathrm{NF}_{\kappa} \mathrm{B}$ activation. PW cells were incubated with RPMI containing BSO $(1 \mathrm{mM})$ for 1,3 and $5 \mathrm{~h}$. Post cytosolic nuclear fractions were prepared from digitonin permeabilized cells as described in the Materials and Methods section. Rel A tranlocation was determined by immunoblot analysis performed on nuclear fractions, and shows the Rel A protein band at $65 \mathrm{k}-\mathrm{Da}$. Equal amounts of protein $(50 \mu \mathrm{g})$ were loaded in each lane (determined by the Biorad assay). (B) Effect of BSO incubation on p53 induction. PW cells were incubated with RPMI containing BSO (1 mM) for $24,48,72$ and $96 \mathrm{~h}$. The expression of p53, p21waf1 and truncated p53 was determined by immunoblot analysis described in the Materials and Methods section. Equal amounts of protein $(50 \mu \mathrm{g})$ were loaded in each lane (determined by the BioRad assay)

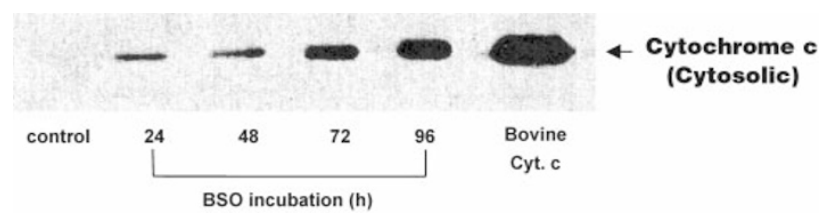

Figure 6 Cytochrome $c$ release after incubation with BSO. PW cells were incubated with BSO $(1 \mathrm{mM})$ for $0,24,48,72$ and $96 \mathrm{~h}$. The cytosolic fraction was recovered by digitonin permeabilization as described in the Materials and Methods section. Cytochrome $c(15 \mathrm{k}-\mathrm{Da})$ was determined by immunoblot analysis. Bovine cytochrome $c$ was used as a positive control. Equal amounts of protein $(25 \mu \mathrm{g})$ were loaded in each lane (determined by the BioRad assay)

It is known that GSH is an important regulator of the cellular redox state. However, the relative importance of cytosolic and mitochondrial GSH levels as mediators of apoptotic signaling has not been clearly defined. Mitochondria do not possess the enzymes required for de novo GSH synthesis, ${ }^{40}$ but utilize cytosolic GSH derived from a multicomponent, ATP dependent, mitochondrial transporter that translocates GSH from the cytosol into the mitochondrial matrix. ${ }^{41,42}$ The transporter has a high affinity component which functions at low cytosolic GSH levels, to maintain mitochondrial GSH levels during periods of cytosolic GSH depletion. ${ }^{41}$ Evidence for this transporter function in PW cells is provided by the observation that after cytosolic GSH depletion, the enriched mitochondrial GSH fraction still contains approximately $25 \%$ of the pretreatment GSH content compared with untreated control samples. After $48 \mathrm{~h}$ of treatment with $\mathrm{BSO}, \mathrm{GSH}$ was undetectable in
A

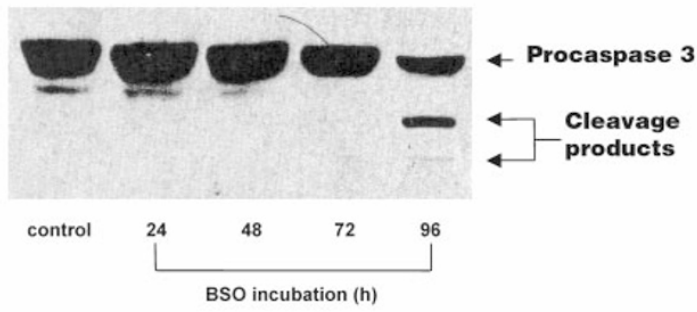

B

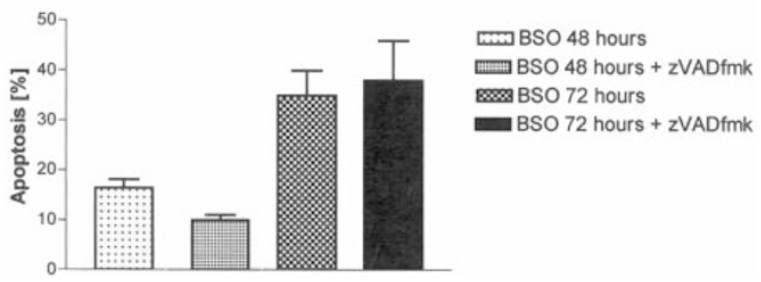

Figure 7 (A) Caspase 3 activation after incubation with BSO. PW cells were incubated with BSO (1 mM) for 0, 24, 48, 72 and $96 \mathrm{~h}$. Caspase 3 (32 k-Da) activation was determined by immunoblot analysis and shows the protein band at $32 \mathrm{k}-\mathrm{Da}$. Caspase cleavage products were observed at $72 \mathrm{~h}$ after BSO treatment. Equal amounts of protein $(20 \mu \mathrm{g})$ were loaded in each lane (determined by the Biorad assay). (B) Inhibition of apoptosis by zVADfmk. PW cells were incubated with RPMI containing BSO $(1 \mathrm{mM})$ for 48 and $72 \mathrm{~h}$. zVADfmk was then added to cultures, and cultures were incubated for an additional $24 \mathrm{~h}$ as described in the Materials and Methods section. Apoptosis was assessed by FACS analysis of PI stained cells. Data are expressed as mean \pm S.E.M. $(n=3)$

mitochondrial fractions. This finding suggests that during cytosolic GSH depletion the mitochondrial GSH pool also loses GSH, but at a slower rate. Since it is known that the mitochondrial electron transport chain is a major source of cellular ROS, retention of GSH by mitochondria may be an important mechanism for protection againt ROS. ${ }^{43,44}$ ROS production following $48 \mathrm{~h}$ of BSO treatment was followed by an increased apoptotic fraction (flow cytometry analysis of PI stained cells), and an increased proportion of non-viable cells (detected by flow cytometry analysis, showing an increased proportion of non-fluorescent DCF stained cells and an increased in sub-G1 P1 stained cells), which was prevented by coincubation of cells with BSO and DTT. These observations are consistent with the hypothesis that mitochondrial ROS may be important effector molecules for the induction of apoptosis, ${ }^{43,44}$ and that the level of ROS generated may be a determinant of the apoptotic potential of cells. ${ }^{44,45}$ Elegant work by Tan et al. ${ }^{46}$ is in agreement with our data and also suggests that mitochondrial generation of ROS plays a role in the induction of apoptosis. They found that while GSH depletion was necessary for an initial increase in ROS production, that GSH depletion alone was not sufficient to generate the late exponential increase in mitochondrial ROS observed in a murine hippocampal cell line (HT22) after treatment with glutamate. A high rate of ROS production occurred only after GSH levels dropped below $\sim 20 \%$ of baseline in the HT22 cells. The results reported here minimal ROS 

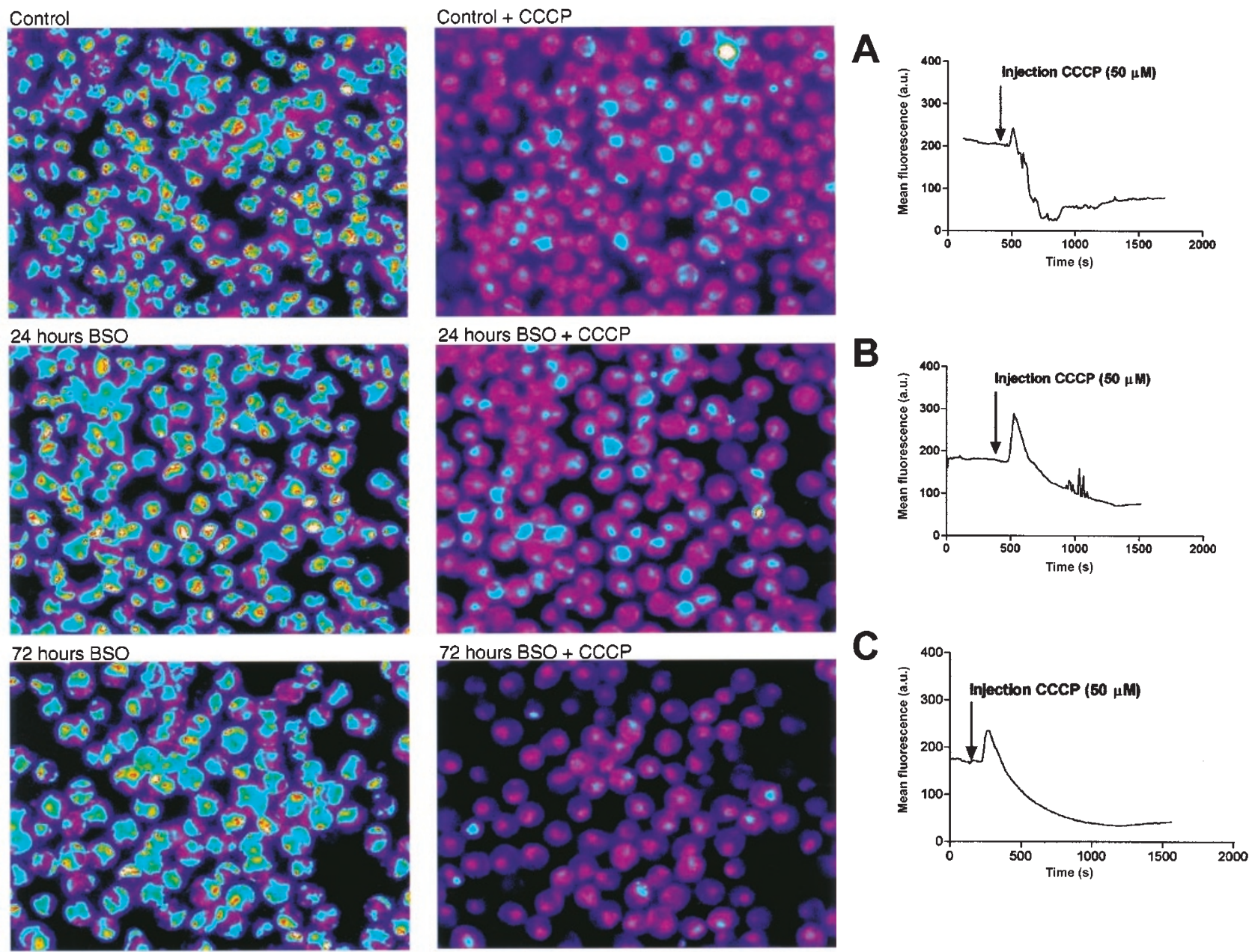

Figure 8 Mitochondrial membrane potential $\left(\Delta \Psi_{m}\right)$ after incubation with BSO. (A) $\Delta \Psi_{m}$ after incubation with BSO. PW cells were incubated with BSO (1 mM) for 0 , 24 , and $72 \mathrm{~h}$. Cells were loaded with the dye TMRM, and $\Delta \Psi_{\mathrm{m}}$ was determined in these cells by monitoring the intensity in fluroescence of the dye. After establishment of baseline fluorescence ( $\geqslant 20 \mathrm{~min})$, the uncoupler CCCP $(50 \mu \mathrm{M})$ was perfused into the system and the fluorescence of $\geqslant 20$ representative cells was monitored at $10 \mathrm{~s}$ intervals for 200 additional measurements. (B) $\Delta \Psi_{\mathrm{m}}$ after incubation with BSO. Graphical representation of the mean TMRM fluorescence of PW cells $(\mathbf{A})$ control (B) incubation with BSO $(1 \mathrm{mM})$ for $24 \mathrm{~h}$ and $(\mathbf{C})$ incubation with BSO $(1 \mathrm{mM})$ for $72 \mathrm{~h}$. The TMRM fluorescence of 20 randomly picked cells was monitored before and after perfusion with $\operatorname{CCCP~}(50 \mu \mathrm{M})$ for a total time of $25 \mathrm{~min}$. This fluorescence was averaged and plotted as a function of time after the background fluorescence had been subtracted

generation after cytosolic GSH depletion, but a large increase in ROS production after mitochondria are depleted of GSH. It is probable that in both HT22 and PW cells, the large increase in ROS generation following GSH depletion is primarily related to the induction of apoptosis, rather than being a direct and simple response to the GSH depletion alone.

The transcription factor $\mathrm{NF} \kappa \mathrm{B}$ plays an important role in inducing genes involved in inflammation, protective responses, ${ }^{17}$ and apoptosis. ${ }^{18-23}$ Activation of $N F \kappa B$ is redox sensitive, ${ }^{14-16}$ and oxidants have been shown to increase $\mathrm{NF}_{\kappa} \mathrm{B}$-mediated expression of c-fos, c-jun and AP1. ${ }^{47,48}$ Here we report that the Rel A component of $\mathrm{NF} \kappa \mathrm{B}$ translocates to the nucleus early after GSH depletion, before increased ROS levels are detectable. Interestingly, Hoare et al. ${ }^{49}$ reported cytokine-induced $\mathrm{NF}_{\kappa} \mathrm{B}$ activation was also independent of ROS production.
The p53 protein is a tumor suppressor gene product Increased levels of p53 have been found to block cell proliferation by inducing the transcription of other regulatory genes such as p21 ${ }^{\text {waf1 }} \cdot{ }^{25,26}$ Since p53 is induced after genotoxic stress, we performed experiments to determine whether or not the stress imposed by GSH depletion induced p53 expression. We found that p53 was constitutively expressed at high levels in PW cells, and GSH depletion did not induce p2 $1^{\text {waf1 }}$ expression (data not shown). Therefore, we suggest that PW cell growth arrest following GSH depletion was p21 $21^{\text {waf1 }}$ independent. It is possible that p21 expression is not increased along with truncated p53 because $\mathrm{p} 21^{\text {waf1 }}$ induction by oxidative stress is independent of the induction of p53. It is also possible that unlike wild-type p53, truncated p53 may not act as a transcriptional activator for $\mathrm{p} 21^{\text {waf1 }}$. Interestingly, Esposito et al. ${ }^{50}$ recently showed that modulation of intracellular redox status with diethylmaleate, also a glutathione-depleting agent, induced a p53- 
independent growth arrest that was mediated by the accumulation of $\mathrm{p} 21^{\text {waf1 }}$

Despite the known role of p53 as a mediator of growth arrest, the precise mechanism(s) involved in p53-dependent apoptosis have not been fully elucidated. ${ }^{24,25}$ Interestingly, we found trace levels of truncated p53 after $24 \mathrm{~h}$ of incubation with BSO, which increased in a timedependent manner, with the highest levels observed when apoptosis was irreversibly induced. Truncated p53 lacks the $\mathrm{N}$ terminus binding region for $\mathrm{mdm}-2$, and may be unable to negatively induce the p53 target gene mdm-2. ${ }^{24}$ Since mdm-2 can block both p53-mediated cell cycle arrest and apoptosis, ${ }^{24,25}$ truncated p53 may function as a positive inducer of apoptosis ${ }^{24}$ in PW cells.

Since cytochrome $c$ has been shown to activate apoptosis, ${ }^{51,52}$ experiments were performed to determine whether induction of apoptosis in the PW cell line involved cytochrome $c$ or the downstream caspase 3 pathway. Cytochrome $c$ release in response to incubation with BSO increased in a time-dependent manner. When the labile cytosolic GSH pool was depleted, after approximately $24 \mathrm{~h}$ of BSO treatment, mitochondria released only trace amounts of cytochrome $c$. However, after incubation with BSO for $72 \mathrm{~h}$, relatively large quantities of cytosolic cytochrome $c$ were detected by immunoblot. Therefore, mitochondria of PW cells release cytochrome $c$ after $\mathrm{GSH}$ depletion, but before increased levels of ROS are detectable. These results are in agreement with those of Ghibelli et al., ${ }^{36}$ however, they reported the release of large quantities of cytochrome $c$ from HepG2 and U937 mitochondria as early as $3 \mathrm{~h}$ after incubation with BSO, which did not commit these cells to apoptosis. It is not clear from our findings whether cytochrome $c$ is released from cells as a consequence of apoptosis, or it if is an early signal for the induction of redox-dependent apoptosis. However, the observation that we were able to rescue many cells from subsequent cell death by withdrawal of BSO after $\leqslant 48 \mathrm{~h}$ incubation, despite the release of detectable amounts of cytochrome $c$ release, suggests that cytochrome $c$ release from mitochondria may not irreversibly commit cells to death.

Procaspase 3 protein levels decreased as a function of time of incubation with BSO, and after $96 \mathrm{~h}$, caspase 3 cleavage products were observed (Figure 6A). These data are supported by a recent study by Chen et al. ${ }^{53}$ who reported that procaspase 3 cleavage could be induced with $\mathrm{H}_{2} \mathrm{O}_{2}$. Furthermore, Yoshimura et al. ${ }^{54}$ showed that hypoxia-induced pro-caspase 3 activation is blocked by GSH. Since, the activation of caspase proenzymes occurs by cleavage at specific aspartate cleavage sites, ${ }^{36}$ oxidative modification of cysteine sulfhydryls in the caspase 3 protein may be involved in cleavage of the protein. ${ }^{36}$ The oxidizing conditions created by BSO treatment may play a role in these cleavage reactions and results in procaspase 3 activation. The results reported here with the zVADfmk pan-caspase inhibitor further confirm the involvement of procaspase activation in BSO-mediated apoptosis, and demonstrate that following incubation with BSO for $48 \mathrm{~h}$, when mitochondrial GSH is depleted, that increased ROS generation precedes procaspase 3 activation.
The role of $\Delta \Psi_{\mathrm{m}}$ depolarization as an apoptotic signal is controversial. $8,32,38,39$ Here we report that neither early GSH depletion, nor later increased ROS caused dissipation of the $\Delta \Psi_{\mathrm{m}}$, with similar TMRM fluorescence in control and BSO $(72 \mathrm{~h})$ treated samples. This result is surprising because it has previously been reported that loss of $\Delta \Psi_{\mathrm{m}}$ is an early and irreversible signal for apoptosis. ${ }^{32}$ The preservation of $\Delta \Psi_{\mathrm{m}}$ after $\mathrm{GSH}$ depletion and ROS production indicates that $\Delta \Psi_{\mathrm{m}}$ depolarization may not play a causal role in redox-dependent apoptosis in the PW cell line. These observations have been recently substantiated in a study where it was shown that caspases were activated independently of dissipation of the $\Delta \Psi_{m}$ during apoptosis. $^{55}$ The integrity of the MPT pore is also dependent upon the redox environment of the cell. ${ }^{56,57}$ Petronilli et al. ${ }^{58}$ found that the MPT pore complex contains a critical thiol residue that is in redox equilibrium with $\mathrm{GSH}$. Therefore, modulation of the cellular redox state could increase the gating potential of the MPT pore and promote the dissipation of $\Delta \Psi_{\mathrm{m}}$. Since the release of cytochrome $c$ was evident at $24 \mathrm{~h}$ after GSH depletion, it is possible that cytochrome $c$ release is regulated by determinants other than $\Delta \Psi_{\mathrm{m}}{ }^{59}$

In conclusion, the loss of mitochondrial GSH appears to be a key regulator of apoptotic potential in PW cells, since the subsequent increase in ROS production precedes the induction of apoptosis. GSH depletion in PW cells is sequentially associated with a decline in total cellular $\mathrm{GSH}$, along with $\mathrm{NF}_{\kappa} \mathrm{B}$ activation, the release of cytochrome $c$ from mitochondria, and the expression of a truncated form of $p 53$. ROS production is then increased, at which time pro-caspase 3 is cleaved and apoptosis is irreversibly induced. Future experiments will be designed to further elucidate the role of $\Delta \mathrm{p} 53$, wild-type p53, and $\mathrm{NF} \kappa \mathrm{B}$ in this process and to test the hypothesis that $\Delta p 53$ and $\mathrm{NF} \kappa \mathrm{B}$ are direct mediators of survival/apoptotic signals in this system. Since ionizing radiation and chemotherapy alter redox status, elucidation of the role of redox modulation on apoptotic signaling pathways may have broad clinical relevance and ultimately allow for the development of novel therapeutic strategies to improve the efficacy of cytotoxic therapies.

\section{Materials and Methods}

\section{Cell culture and treatments}

PW cells (a kind gift from Dr. Amato Giaccia, Stanford University) were cultured in RPMI medium supplemented with $10 \%(\mathrm{v} / \mathrm{v})$ fetal bovine serum (FBS), $300 \mu \mathrm{g} / \mathrm{l}$ L-Glutamine, $100 \mu \mathrm{g} / \mathrm{ml}$ streptomycin, and $100 \mathrm{U} / \mathrm{ml}$ penicillin. They were incubated in a controlled atmosphere $\left(5 \% \mathrm{CO}_{2}\right)$ incubator at $37^{\circ} \mathrm{C}$, and were split every 2 days to maintain them in log-phase. Cultures were maintained at a concentration of between $5 \times 10^{5} / \mathrm{ml}$ and $1 \times 10^{6} / \mathrm{ml}$ to prevent apoptosis induced by overgrowth, and all experiments were performed at a cell density of $5 \times 10^{5} \mathrm{cells} / \mathrm{ml}$. GSH was depleted with BSO $(1 \mathrm{mM})$ which inhibits the cytosolic gamma glutamyl cysteine synthetase ( $\gamma \mathrm{GCS}$ ). Experiments were also performed with dithiotreitol (DTT) at $500 \mu \mathrm{M}$ (Sigma, St. Louis, MO, USA) and BSO to determine if DTT could protect cells 
from the effects of BSO on ROS generation and the induction of apoptosis. The protonophore carbonyl cyanide $m$-chlorophenylhydrazone (CCCP) $50 \mu \mathrm{M}$ was used to induce $\Delta \Psi_{\mathrm{m}}$ depolarization.

\section{Cell viability and apoptosis assays}

Cell viability was assessed by flow cytometry using propidium iodide (PI) to differentiate between cells with and without intact plasma membranes. Since the nuclei in apoptotic cells contain hypodiploid amounts of DNA, flow cytometry analysis of PI stained permeabilized cells was used to quantitate the percentage of apoptotic (sub-G1) cells as previously described. ${ }^{8}$

\section{Rescue of PW cells after BSO incubation}

PW cells were incubated (under standard conditions in RPMI 1640 containing $10 \%$ FBS, and supplements) with BSO (1 mM) for 0, 12, 24, $36,48,60$ and $72 \mathrm{~h}$. Cells were then washed in fresh RPMl 1640 to remove the BSO, and seeded at a density of $5 \times 10^{5} / \mathrm{ml}$ in fresh RPMI 1640 for an additional $72 \mathrm{~h}$. At 24, 48 and $72 \mathrm{~h}$ after removal of the BSO cell proliferation was assessed by cell cytometry of PI stained cells.

\section{Measurement of glutathione}

GSH was measured as previously described. ${ }^{8}$ Briefly, PW cell samples $\left(4 \times 10^{6}\right)$ were rinsed in phosphate buffered saline and sonicated for $10 \mathrm{~s}$ on ice. Proteins were precipitated on ice for $15 \mathrm{~min}$ with sulfosalicylic acid (6.5\%) and centrifuged at $2000 \times g$ for $15 \mathrm{~min}$ at $4^{\circ} \mathrm{C}$. Supernatants were stored at $-70^{\circ} \mathrm{C}$ until the time of analysis. GSH in enriched mitochondrial fractions was determined on samples that had been previously permeabilized with digitonin to release the cytosol. Post cytosolic cell fractions were washed three times in icecold PBS and centrifuged. Cell pellets were processed in an identical manner to whole cells. GSH was determined by the GSH-reductase recycling assay, ${ }^{60}$ in microtitre plates.

\section{ROS determination}

Dichorofluorescein diacetate (DCFH-DA) was used to assess levels of net intracellular generation of ROS. ${ }^{61}$ DCFH-DA is a peroxidesensitive fluorescent probe that is nonpolar and diffuses into the cell. Intracellular esterases cleave the diacetate ester group and entrap the polar, nonfluorescent DCFH within the cell. ROS can oxidize this substance to the fluorescent compound DCF. Cells were treated with BSO (1 mM) for the indicated times, and washed in Hanks Buffered Saline Solution (HBSS) (Gibco, Gaithersburg, MD, USA). One $\times 10^{6} /$ $\mathrm{ml}$ cells were incubated in HBSS containing $50 \mu \mathrm{M}$ DCFH-DA for 30 min prior to ROS measurement. Samples incubated with hydrogen peroxide $(100 \mu \mathrm{M})$ were used as a positive control. The fluorescence of the cell population is proportional to the levels of intracellular ROS generated, ${ }^{61}$ and was measured with a FACScan (Becton Dickinson, Mountain View, CA, USA) at $588 \mathrm{~nm}$ emission.

\section{Immunoblotting}

For immunoblotting post cytosolic (nuclear) fractions and cytosolic fractions were obtained from digitonin permeabilized PW cells as previously described. ${ }^{8}$ Nuclear fractions were used to determine Rel A protein levels. Briefly, $3-5 \times 10^{6}$ cells were harvested and resuspended in $100 \mu \mathrm{l}$ of mitochondrial isolation buffer $(250 \mathrm{mM}$ mannitol, $17 \mathrm{mM}$ MOPS (pH 7.4), $2.5 \mathrm{mM}$ EDTA and $0.2 \mathrm{mg} / \mathrm{ml}$ digitonin). The suspension was centrifuged at 3000 r.p.m. for $5 \mathrm{~min}$ at $4{ }^{\circ} \mathrm{C}$ and the cell pellet was washed twice in ice cold PBS. After re-suspension in $200 \mu$ l sodium dodecyl sulfate (SDS) buffer, the extract was boiled for
$10 \mathrm{~min}$ to denature the proteins. The cell extract was aspirated through a 27 gauge needle and transferred to a new tube. The protein concentration was measured using a protein assay kit (DC protein assay reagent, Bio-Rad, Hercules, CA, USA). Fifty micrograms of denatured protein were resolved on $10 \%$ SDS-PAGE gels and electro-blotted onto nitrocellulose membrane. Rel $A$ was detected using a rabbit polyclonal antibody to Rel A $(1: 250)$ for $1 \mathrm{~h}$ (Santa Cruz, San Diego, CA, USA). Membranes were incubated in anti-speciesHRP conjugated secondary antibody for $1 \mathrm{~h}$ at (1:1000) (Dako, Carpinteria, CA, USA). Detection was carried out by incubating membranes for $5 \mathrm{~min}$ with the enhanced chemiluminescence reagent (ECL kit; Amersham Pharmacia Biotech), followed by exposure to ECL X-ray film (Amersham).

For cytochrome $c$, cytosolic fractions recovered from digitonin permeabilized cells were mixed $(1: 1)$ with SDS sample buffer and boiled to denature the proteins. Thirty micrograms of cytosolic protein extracts were resolved on 15\% SDS-PAGE gels, and electro-blotted onto a nitrocellulose membrane (BioRad). Anti-cytochrome $c$ mouse monoclonal antibody (PharMingen, San Diego, CA, USA) was used as the primary antibody. Membranes were incubated in anti-species-HRP conjugated secondary antibody for $2 \mathrm{~h}$ at $(1: 1000)$ (Dako). Detection was carried out by incubating membranes for 5 min with the ECL reagent (Amersham) as described for Rel A.

For p53, cells were initially washed in ice cold PBS and were pelleted and resuspended in UTB buffer (9 $\mathrm{M}$ urea, $75 \mathrm{mM}$ Tris- $\mathrm{HCl}$, $\mathrm{pH}$ 7.5, $0.15 \mathrm{M}$ 2-mercaptoethanol) and sonicated briefly. The protein concentration was determined as described above (Bio Rad). Fifty micrograms of protein were separated on SDS-PAGE gels and electro-blotted on to nitrocellulose membranes (Osmonics, Westborough, MA, USA). Proteins were detected with the following antibodies: mouse mAb against the N- (DO-1, Santa Cruz, CA, USA) and C-(pAb 421) termini of $p 53$, and mouse $m A b$ against p21 WAF1/CIP1 (Chemicon International Inc., Temecula, CA, USA). Membranes were incubated in anti species-HRP conjugated secondary antibody for $1 \mathrm{~h}$ at $(1: 1000)$ (Dako). Detection was carried out by incubating membranes with the enhanced chemiluminescence reagent ((ECL kit; Amersham) Pharmacia Biotech), followed by exposure to ECL Xray film (Amersham) as described for Rel $A$.

For caspase 3, $20 \mu \mathrm{g}$ of denatured protein were resolved on $12 \%$ SDS-PAGE gels and electro-blotted onto nitrocellulose membranes. The membrane was incubated with mouse anti-human CPP32 monoclonal antibody (Calbiochem, La Jolla, CA, USA) as the primary antibody $(1: 500)$ for $1 \mathrm{~h}$. Membranes were incubated in anti speciesHRP conjugated secondary antibody for $2 \mathrm{~h}$ at (1:1000) (Dako). Detection was carried out by incubating membranes for 5 min with the (ECL kit; Amersham) as described for Rel A.

\section{Apoptosis following BSO incubation and addition of the caspase inhibitor zVADfmk}

PW cells were incubated with RPMI containing BSO ( $1 \mathrm{mM})$ for 48 and $72 \mathrm{~h}$ after which time the broad spectrum caspase inhibitor benzyloxycarbonyl-val-glu-asp fluoromethylketone (zVADfmk) $(50 \mu \mathrm{M})$ or vehicle control (DMSO) was added, the cultures were incubated for an additional $24 \mathrm{~h}$. Apoptosis was assessed by flow cytometry analysis of $\mathrm{PI}$ stained cells. Data are expressed as mean \pm S.E.M. $(n=3)$.

\section{Analysis of the mitochondrial membrane potential}

Mitochondrial membrane potential was determined by measuring the fluorescence of cells stained with the dye tetra-methyl rhodamine 
methyl ester (TMRM) before and after exposure to BSO $(1 \mathrm{mM})$ and/or CCCP $(50 \mu \mathrm{M})$ in at least 20 individual cells. Cells $\left(2 \times 10^{6} / \mathrm{ml}\right)$ loaded with TMRM ( $150 \mathrm{nM}$ ) were seeded onto glass cover slips (previously coated with polylysine) in $1 \mathrm{ml}$ of RPMI 1640 with $10 \%$ FBS and left to attach for $30 \mathrm{~min}$ at $37^{\circ} \mathrm{C}$. Cells were transferred to a temperaturecontrolled perfusion chamber (Bioptechs, Butler, PA, USA). During the experiment, cells were maintained at $37^{\circ} \mathrm{C}$ in culture media containing $50 \mathrm{nM}$ TMRM. Fluorescence images were obtained with a cooled CCD camera (Photometrics Quantix, Tuscon, AZ, USA) connected to an epifluorescence inverted microscope (Nikon TE 300) equipped with a $40 \times$ oil immersion objective. Excitation light from a $75 \mathrm{~W}$ zenon arc lamp was coupled to the microscope by a liquid light guide (Sutter Instrument Co., Navato, CA, USA) and directed onto a filter cube $(535 \pm 25 \mathrm{~nm}$ excitation, $575 \mathrm{~nm}$ dichroic mirror, $590 \mathrm{~nm}$ long pass emission filter). Exitation light was reduced by $>90 \%$ with neutral density filters and a computer controlled shutter to minimize photobleaching and phototoxicity. Images were collected for $250 \mathrm{~ms}$ every $10 \mathrm{~s}$ and analyzed using Metafluor imaging software (Universal Imaging, West Chester, PA, USA). To further determine that the mitochondrial membrane potential was intact, CCCP $(50 \mu \mathrm{M})$ was injected into the perfusate and the fluorescence of $\geqslant 20$ representative cells was monitored at $10 \mathrm{~s}$ intervals for a total of 500 measurements per cell. The intensity of the fluorescence was monitored kinetically, and averaged for $\geqslant 20$ cells over the total time period.

\section{Statistical analysis}

Statistical analyses were performed using Student's $t$-test for unpaired data, and $P$ values $<0.05$ were considered significant. Data are presented as mean \pm S.E.M.

\section{Acknowledgments}

The authors thank Chuck Diban for his assistance with the preparation of this manuscript and Dr. Jeff Carson for his assistance with the figures. we also thank Dr. Garry Nolan for his support of the flow cytometry work represented in this manuscript. This work was supported, in part by Grant PHS NRSA 5T32 CA09302 (JS Armstrong), the Kurt and Senta Herrmann-Foundation and the Swiss Cancer League (Zürich) (KK Steinauer), a James H. Clark Stanford Graduate Fellowship (JM Irish), an Australian National Health and Medical Research Council Fellowship 997034 (GW Birrell) and the Department of the Army DAMP 17-99-19004 (DM Peehl and P Lecane).

\section{References}

1. Rupnow BA, Murtha AD, Alarcon RM, Giaccia AJ and Knox SJ (1998) Direct evidence that apoptosis enhances tumor responses to fractionated radiotherapy. Cancer Res. 58: 1779-1784

2. Alemany M and Levin J (2000) The effects of arsenic trioxide (As2O3) on human megakaryocytic leukemia cell lines. With a comparison of its effects on other cell lineages. Leuk. Lymphoma 38: 153-163

3. Mallery SR, Clark YM, Ness GM, Minshawi OM, Pei P and Hohl CM (1999) Thiol redox modulation of doxorubicin mediated cytotoxicity in cultured AIDS-related Kaposi's sarcoma cells. J. Cell. Biochem. 73: 259-277

4. Dolan ME, Frydman B, Thompson CB, Diamond AM, Garbiras BJ, Safa AR, Beck WT and Marton LJ (1998) Effects of 1,2-naphthoquinones on human tumor cell growth and lack of cross-resistance with other anticancer agents. Anticancer Drugs 9: 437-448

5. Green DR and Reed JC (1998) Mitochondria and apoptosis. Science 281:13091312
6. Marchetti P, Decaudin D, Macho A, Zamzami N, Hirsch T, Susin SA and Kroemer G (1997) Redox regulation of apoptosis: impact of thiol oxidation status on mitochondrial function. Eur. J. Immunol. 27: 289-296

7. Coffey RN, Watson RW, Hegarty NJ, O'Neill A, Gibbons N, Brady HR and Fitzpatrick JM (2000) Thiol-mediated apoptosis in prostate carcinoma cells. Cancer 88: 2092-2104

8. Armstrong JS, Steinauer KK, Killoran P, Walleczek Y and Knox S (2001) Bcl-2 inhibits apoptosis after mitochondrial 'uncoupling' but does not prevent mitochondrial transmembrane depolarization. Exp. Cell. Res. 262: 170-179

9. Deneke SM and Fanburg BL (1989) Regulation of cellular glutathione. Am. J. Physiol. 257: L163-L173

10. Fernandez-Checa JC, Kaplowitz N, Garcia-Ruiz C, Colell A, Miranda M, Mari M, Ardite $\mathrm{E}$ and Morales A (1997) GSH transport in mitochondria: defense against TNF-induced oxidative stress and alcohol-induced defect. Am. J. Physiol. 273: G7-G17

11. Buttke TMand Sandstrom PA (1994) Oxidative stress as a mediator of apoptosis. Immunol. Today 15: 7-10

12. Langer C, Jurgensmeier JM and Bauer G (1996) Reactive oxygen species act at both TGF-beta-dependent and -independent steps during induction of apoptosis of transformed cells by normal cells. Exp. Cell. Res. 222: 117-124

13. Hug H, Enari $M$ and Nagata $S$ (1994) No requirement of reactive oxygen intermediates in Fas-mediated apoptosis. FEBS Lett. 351: 311-313

14. Arrigo AP (1999) Gene expression and the thiol redox state. Free Radic. Biol. Med. 27: 936-944

15. Sen CK (2000) Cellular thiols and redox-regulated signal transduction. Curr. Top Cell Regul. 36: 1-30

16. Hutter D and Greene JJ (2000) Influence of the cellular redox state on NFkappaB-regulated gene expression. J. Cell Physiol. 183: 45-52

17. Palayoor ST, Youmell MY, Calderwood SK, Coleman CN and Price BD (1999) Constitutive activation of IkappaB kinase alpha and NF-kappaB in prostate cancer cells is inhibited by ibuprofen. Oncogene 18: 7389-7394

18. Baeuerle PA and BaltimoreD (1996) NF-kappa B: ten years after. Cell 87:13-20

19. Wang CY, Mayo MW, Korneluk RG, Goeddel DV and Baldwin Jr AS (1998) NFkappaB antiapoptosis: induction of TRAF1 and TRAF2 and c-IAP1 and c-IAP2 to suppress caspase-8 activation. Science 281: 1680-1683

20. WuMX, AoZ, PrasadKV, Wu Rand Schlossman SF (1998) IEX-1L, an apoptosis inhibitor involved in NF-kappaB-mediated cell survival. Science 281: 998-1001

21. Hettmann T, DiDonato J, Karin M and Leiden JM (1999) An essential role for nuclear factor kappaB in promoting double positive thymocyte apoptosis. J. Exp. Med. 189: 145-158

22. Post A, Crochemore C, Uhr M, Holsboer F and Behl C (2000) Differential induction of NF-kappaB activity and neural cell death by antidepressants in vitro. Eur. J. Neurosci 12: 4331-4337

23. Panet H, Barzilai A, Daily D, Melamed E and Offen D (2001) Activation of nuclear transcription factor kappa B (NF-kappaB) is essential for dopamine-induced apoptosis in PC12 cells. Neurochemistry 77: $391-398$

24. Okorokov AL, Ponchel Fand Milner J (1997) Induced N-and C-terminal cleavage of $p 53$ : a core fragment of $p 53$, generated by interaction with damaged DNA, promotes cleavage of the $\mathrm{N}$-terminus of full-length $\mathrm{p} 53$, whereas ssDNA induces C-terminal cleavage of p53. EMBO J. 16: 6008-6017

25. Chen J, Wu X, Lin J and Levine AJ (1996) mdm-2 inhibits the G1 arrest and apoptosis functions of the p53 tumor suppressor protein. Mol. Cell. Biol. 16: $2445-2452$

26. Polyak K, Xia Y, Zweier JL, Kinzler Kw and Vogelstein B (1997) A model for p53induced apoptosis. Nature 389: 300-305

27. Kroemer G, Zamzami N and Susin SA (1997) Mitochondrial control of apoptosis. Immunol. Today 18: 44-51

28. Kroemer G (1996) Mitochondrial control of nuclear apoptosis. J. Exp. Med. 183: $1533-1544$

29. Hirsch T, Marzo I and Kroemer G (1997) Role of the mitochondrial permeability transition pore in apoptosis. Biosci. Rep. 17: 67-76

30. Marchetti P, Castedo M, Susin SA, Zamzami N, Hirsch T, Macho A, Haeffner A, Hirsch F, Gueskens M and Kroemer G (1996) Mitochondrial permeability transition is a central coordinating event of apoptosis. J. Exp. Med. 184: 1155-1160

31. Crompton $M(1999)$ The mitochondrial permeability transition pore and its role in cell death. Biochem. J. 341: 233-249

32. Zamzammi N, Marchetti P, Castedo M, Zanin C, Vayssiere JL, Petit PX and Kroemer G (1995) Reduction in mitochondrial potential constitutes an early irreversible step of programmed lymphocyte death in vivo. J. Exp. Med. 181: $1661-1672$ 
33. Li P, Nijhawan D, Budihardjo I, Srinivasula SM, Ahmad M, Alnemri ES and Wang X (1997) Cytochrome $c$ and dATP-dependent formation of Apaf-1/caspase-9 complex initiates an apoptotic protease cascade. Cell 91: 479-489

34. Ghibelli L, Coppola S, Fanelli C, Rotilio G, Civitareale P, Scovassi Al and Ciriolo MR (1999) Glutathione depletion causes cytochrome $c$ release even in the absence of cell commitment to apoptosis. FASEB J. 13: 2031-2036

35. Budd SL, Tenneti L, Lishnak T and Lipton SA (2000) Mitochondrial and extramitochondrial apoptotic signaling pathways in cerebrocortical neurons. Proc. Natl. Acad. Sci. USA 97: 6161-6166

36. Hampton MB, Fadeel B and Orrenius S (1998) Redox regulation of the caspases during apoptosis. N.Y. Acad. Sci. 854: 328-335

37. Baker A, Santos BD and Powis G (2000) Redox control of caspase-3 activity by thioredoxin and other reduced proteins. Biochem. Biophys. Res. Commun. 268 : $78-81$

38. Minamikawa T, Williams DA, Bowser DN and Nagley P (1999) Mitochondrial permeability transition and swelling can occur reversibly without inducing cell death in intact human cells. Exp. Cell. Res. 246: 26-37

39. Finucane DM, Waterhouse NJ, Amarante-Mendes GP, Cotter TG and Green DR (1999) Collapse of the inner mitochondrial transmembrane potential is not required for apoptosis of HL60 cells. Exp. Cell. Res. 251: 166-174

40. Griffith OW and Meister A (1985) Origin and turnover of mitochondrial glutathione. Proc. Natl. Acad. Sci. USA 82: 4668-4672

41. Martensson J, LaiJC and Meister A (1990) High-affinity transport of glutathione is part of a multicomponent system essential for mitochondrial function. Proc. Natl. Acad. Sci. USA 87: 7185-7189

42. Garcia-Ruiz C, Morales A, Colell A, Rodes J, Yi JR, Kaplowitz N and FernandezCheca JC (1995) Evidence that the rat hepatic mitochondrial carrier is distinct from the sinusoidal and canalicular transporters for reduced glutathione. Expression studies in Xenopus laevis oocytes. J. Biol. Chem. 270: 1594615949

43. Suzuki S, Higuchi M, Proske RJ, Oridate N, Hong WK and Lotan R (1999) Implication of mitochondria-derived reactive oxygen species, cytochrome $\mathrm{C}$ and caspase-3 in $\mathrm{N}$-(4-hydroxyphenyl)retinamide-induced apoptosis in cervical carcinoma cells. Oncogene 18: 6380-6387

44. Sanchez A, Alvarez AM, Benito M and Fabregat I (1996) Apoptosis induced by transforming growth factor-beta in fetal hepatocyte primary cultures: involvement of reactive oxygen intermediates. J. Biol. Chem. 271: 7416-7422

45. Li P-F, Dietz R and von Harsdorf R (1999) p53 regulates mitochondrial membrane potential through reactive oxygen species and induces cytochrome $\mathrm{c}$ independent apoptosis blocked by Bcl-2. EMBO J. 18: 6027-6036

46. Tan S, Sagara Y, Liu Y, Maher P and SchubertD (1998) The regulation of reactive oxygen species production during programmed cell death. Cell. Biol. 141:14231432

47. Cerutti P, Shah G, Peskin A and Amstad P (1992) Oxidant carcinogenesis and antioxidant defense. Ann. N.Y. Acad. Sci. 663: 158-166
48. Rahman land MacNeeW(2000) Regulation of redox glutathione levels and gene transcription in lung inflammation: therapeutic approaches. Free Radic. Biol. Med. 28: 1405-1420

49. Hoare GS, Marczin N, Chester AH and Yacoub MH (1999) Role of oxidant stress in cytokine-induced activation of NF-kappaB in human aortic smooth muscle cells. Am. J. Physiol. 277: H1975-H1984

50. Esposito F, Russo L, Russo T and Cimino F (2000) Retinoblastoma protein dephosphorylation is an early event of cellular response to prooxidant conditions. FEBS Lett. 470: 211-215

51. Zou H, Li Y, Liu X and Wang X (1999) An APAF-1 cytochrome c multimeric complex is a functional apoptosome that activates procaspase-9. J. Biol. Chem. 274: $11549-11556$

52. Yang J, Liu X, Bhalla K, Kim CN, Ibrado AM, Cai J, Peng TI, Jones DP and Wang X (1997) Prevention of apoptosis by Bcl-2: release of cytochrome c from mitochondria blocked. Science 275: 1129-1132

53. Chen QM, Liu J and Merrett JB (2000) Apoptosis or senescence-like growth arrest: influence of cell-cycle position, p53, p21 and bax in $\mathrm{H} 2 \mathrm{O} 2$ response of normal human fibroblasts. Biochem. J. 347: 543-551

54. Yoshimura S, Banno Y, Nakashima S, Hayashi K, Yamakawa H, Sawada M, Sakai $N$ and Nozawa $Y(1999)$ Inhibition of neutral sphingomyelinase activation and ceramide formation by glutathione in hypoxic PC12 cell death. J. Neurochem. 73: 675-683

55. LiX, Du Land Darzynkiewicz Z (2000) During apoptosis of HL-60 and U-937 cells caspases are activated independently of dissipation of mitochondrial electrochemical potential. Exp. Cell Res. 257: 290-297

56. Costantini P, ChernyakBV, Petronilli V and Bernardi P (1995) Selective inhibition of mitochondrial permeability transition pore at the oxidation-reduction sensitive dithiol by monobromobimane. FEBS Lett. 362: 239-242

57. Costantini P,Chernyak BV, Petronilli V and Bernardi P (1996) Modulation of the mitochondrial permeability transition pore by pyridine nucleotides and dithiol oxidation at two separate sites. J. Biol. Chem. 271: 6746-6751

58. Petronilli V, Costantini P, Scorrano L, Colonna R, Passamonti S and Bernardi $P$ (1994) The voltage sensor of the mitochondrial permeability transition pore is tuned by the oxidation-reduction state of vicinal thiols. Increase of the gating potential by oxidants and its reversal by reducing agents. J. Biol. Chem. 269: $16638-16642$

59. Vander Heiden MG, Chandel NS, Li XX, Schumacker PT, Colombini M and Thompson CB (2000) Outer mitochondrial membrane permeability can regulate coupled respiration and cell survival. Proc. Natl. Acad. Sci. USA 97: 4666-4671

60. Tietze $F$ (1969) Enzymic method for quantitative determination of nanogram amounts of total and oxidized glutathione: applications to mammalian blood and other tissues. Anal. Biochem. 27: 502-522

61. Bass DA, Parce JW, DechateletLR, Szejda P, Seeds MC and Thomas MJ (1983) Flow cytometric studies of oxidative product formation by neutrophils: a graded response to membrane stimulation. Immunology 130: 1910-1917 